\title{
1 Microwave radiometry experiment for snow in Altay 2 China: in situ time series of data for electromagnetic and 3 physical features of snow pack and environment
}

\author{
Liyun Dai ${ }^{1}$, Tao Che ${ }^{1,2 *}$, Yang Zhang ${ }^{1}$, Zhiguo Ren ${ }^{1,3}$, Junlei Tan ${ }^{1}$, Meerzhan \\ Akynbekkyzy ${ }^{1}$, Lin Xiao ${ }^{1}$, Shengnan Zhou ${ }^{1}$, Yuna Yan ${ }^{3}$, Yan Liu ${ }^{4}$, Hongyi Li ${ }^{1}$, Lifu \\ Wang $^{5}$ \\ ${ }^{1}$ Key Laboratory of Remote Sensing of Gansu Province, Heihe Remote Sensing Experimental Research \\ Station, Northwest Institute of Eco-Environment and Resources, Chinese Academy of Sciences, \\ Lanzhou, 730000, China. \\ ${ }^{2}$ Center for Excellence in Tibetan Plateau Earth Sciences, Chinese Academy of Sciences, Beijing, \\ 100101, China. \\ ${ }^{3}$ University of Chinese Academy of Sciences, Beijing, 1000101, China. yunayan2008@163.com \\ ${ }^{4}$ Institute of Desert Meteorology, China Meteorological Administration, Urumqi, 830002, China \\ ${ }^{5}$ Altay National Reference Meteorological station, China Meteorological Administration, Altay, \\ 836500 , China. \\ Correspondence to: Tao Che (chetao@lzb.ac.cn)
}

Abstract. Snow depth is a key parameter in climatic and hydrological systems. Passive microwave remote sensing, snow process model and data assimilation are the main methods to estimate snow depth in large scale. The estimation accuracies strongly depend on input of snow parameters or characteristics. Because the evolving processes of snow parameters vary spatiotemporally, and are difficult to accurately simulate or observe, large uncertainties and inconsistence exist among existing snow depth products. Therefore, a comprehensive experiment is needed to understand the involution processes of snow characteristics and their influence on microwave radiation of snowpack, evaluating and improving the snow depth and SWE retrieval and simulation methods. An Integrated Microwave Radiometry Campaign for snow (IMCS) was conducted at the Altay National Reference Meteorological station (ANRMS) in Xinjiang, China, during snow season of 2015/2016. The campaign hosted a dual polarized microwave radiometer operating at $\mathrm{L}, \mathrm{K}$ and $\mathrm{Ka}$ bands to provide minutely passive microwave observations of snow cover at a fixed site, daily manual snow pit measurements, ten-minute automatic 4-component radiation and layering snow temperatures, covering a whole snow season of 2015/2016. The measurements of meteorological and underlying soil parameters were requested from the ANRMS. This study provides a summary of the obtained data, detailing measurement protocols for microwave radiometry, in situ sow pit and station observation data. A brief analysis of the microwave signatures against snow parameters is presented. A consolidated dataset of observations, comprising the ground passive microwave brightness temperatures, in situ snow characteristics, 4-component radiation and weather parameters, was achieved in the National Tibetan Plateau Data Center, China. The dataset is unique in providing continuously daily snow pits data over a snow season at a fixed site and matched microwave brightness temperatures, radiation and meteorological data. The dataset is expected to serve for the evaluation and development of the microwave and optical radiative transfer models and snow evolution process models. The 
consolidated data are available at https://data.tpdc.ac.cn/en/ (doi: 10.11888/Snow.tpdc.270886) (Dai, 2020).

Key words: Snow, Microwave radiometry, Snow pit, Experiment

\section{Introduction}

Seasonal snow cover plays a critical role in climate and hydrological systems (Cohen, 1994; Ding et al., 2020; Barnett et al., 2005; Immerzeel et al., 2010) by its high albedo, thermal insulation, fresh water reserves and its phase change process. Snow cover can be accurately identified by optical remote sensing. However, the snow surface albedo was controlled by snow characteristics (Aoki et al., 2003 and 2000), and the variations in snow characteristics cause the uncertainties of albedo estimation. Snow depth and snow water equivalent (SWE) are currently estimated using passive microwave in global and regional scales (Pullianen et al., 2020; Tedesco and Narvekar, 2010; Jiang et al., 2014; Che et al., 2008). Although several global and regional snow depth and SWE products have been released, large uncertainties exist in these products because of the spatio-temporal variations in snow characteristics (Xiao et al., 2020; Mortimer et al., 2020; Che et al., 2016; Dai et al., 2012). Therefore, the observation on electromagnetic and physical parameters of snowpack are necessary to improve understanding the electromagnetic radiation process of snowpack to enhance the estimation accuracy of snow surface albedo and snow depth.

To evaluate and improve snow depth and SWE retrieval methods from passive microwave remote sensing observations and to combine remote sensing technologies with modeling and data assimilation methods for producing the most accurate products, a few large or systematic experiments or campaigns had been conducted on electromagnetic and physical characteristics measurement of snow cover. The Cold Land Processes Field Experiment (CLPX) (https://nsidc.org/data/clpx/index.html) was one of the most well-known experiments, which was carried out from winter of 2002 to spring of 2003 in Colorado, USA (Cline et al., 2003). During the campaign, snow pits were collected at the February and March of 2002 and 2003 to coincide with the airborne and ground remote sensing observations. NASA SnowEx campaign (https://nsidc.org/data/snowex) was conducted in 2017 in Colarado to develop/test algorithms for measurement of SWE in forested and non-forested areas by providing multi-sensor observations of seasonally snow-covered landscapes (Brucker et al., 2017). The campaign is still ongoing and will be conducted in other areas with different snow conditions. In northern Canadian region, mobile sledmounted microwave radiometers were deployed in forest, open and lake environments from November 2009 to April 2010 and snow characteristics within the footprints of radiometers were measured to improve understanding the influence of snow characteristics on brightness temperatures (Derksen et al., 2012; Roy et al., 2013). These microwave experiments were of mobile observation. In these experiments, there were multiple observation sites for different land cover, but relative short temporal range. The snow pit observations could be used for evaluating snow microwave emission model in different land cover (Tedesco and Kim, 2006; Royer et al., 2017), but they did not exhibit the involution of snow parameters.

In the Arctic region, the Nordic Snow Radar Experiment (NoSREx) campaign was conducted at a fixed field in Sodankylä, Finland, during $2009 \sim 2013$ (Lemmetyinen et al., 2016). This experiment provided a continuous time series of active and passive microwave observations of snow cover at a representative location of the Arctic boreal forest area covering a whole winter season and matched snow pit observations were made weekly. In Asia, snow pit work of 3 or 4-day intervals was conducted 
simultaneously with radiation budget observations during winter of 1999/2000 and 2000/2001 to analyze the effects of snow physical parameters on albedo (Aoki et al., 2003). The NoSREx and Japan radiation experiments were of fixed field observation, which provided longer time series of data. These experiments were conducted in deep snow area, and the week-interval observation could reflect the general evolution process of snow characteristics, but might miss some details. Furthermore, in the area with snow cover duration within 4 months, the week-interval observation hardly depicts the change details.

To comprehensively understand the evolutions of snow characteristics and their influence on passive microwave brightness temperatures and radiation budget, an integrated experiment on snow was conducted during a whole snow season, in Altay, China. The experiment was designed to cover periods from snow-free conditions to eventual snow melt-off during 2015/2016. The microwave radiometry measurements at $\mathrm{L}, \mathrm{K}$ and $\mathrm{Ka}$ bands for multiple angles were complemented by a dual-polarized microwave radiometer with 4-component radiation and daily in situ observations of snow, soil and atmospheric properties, using both manual and automated methods. The data of electromagnetic and physical parameters were further consolidated and organized to be easily read and utilized.

The dataset is unique in providing continuously daily snow pits data over a snow season at a fixed site and matched microwave brightness temperatures, radiation and meteorological data. In the next section, the experiment location, parameters, parameter measurement protocols are described; section 3 introduces the consolidated data which was released on the National Tibetan Plateau Data Center, China; section 4 presents content of brightness temperature, 4-component radiation, snow pit data, soil temperature and moisture, and meteorological data; section 5 discusses the possible application; and finally the conclusions are summarized in section 6 .

\section{Description of experiment setup}

\subsection{Measurement location}

The Integrated Microwave Radiometry Campaign for snow (IMCS) was performed during snow season of 2015/2016 (from November 27, 2015 to March 25, 2016) at the Altay National Reference

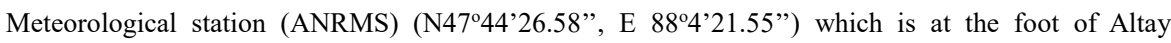
mountain in the northwest China, and approximate $6 \mathrm{~km}$ distance from the mountain (Figure 1). Altay mountain, running northwest and southeast, is at the junction of China, Russia, Mongolia and Kazakhstan, and the elevation is up to $3000 \mathrm{~m}$, providing snow water resources for the four countries. The average annual maximum snow depth measured in this station is approximately $40 \mathrm{~cm}$, and the maximum value is over $70 \mathrm{~cm}$. In the southwest of Altay mountain, crop land and desert with flat terrain are the dominant land covers. Snow cover is critical fresh water for the irrigation in this area. In this experiment, measurements included microwave radiometry, 4-component radiation, snow pit and soil parameters. The test site of this experiment was four neighboring bare rectangle fields in the ANRMS with their area of $2500 \mathrm{~m}^{2}$ (black rectangle filed in Figure 1), $2500 \mathrm{~m}^{2}$ (pink rectangle field in Figure 1), $200 \mathrm{~m}^{2}$ (red rectangle field in Figure 1) and $400 \mathrm{~m}^{2}$ (blue rectangle field in Figure 1), respectively.

In the pink field, the ground-based microwave radiometer was set up in the middle place of this field, facing south to collect brightness temperatures of snow cover. The black field behind the microwave radiometers (north of the radiometers) was for snow pit data collection. The microwave 

Environment and Resources, Chinese Academy of Science (NIEER) from November 27, 2015 to March 25, 2016 (After March 25, 2016, snow melted out).

The blue field is for meteorological measurements including wind speed, wind direction, air temperature, air wetness, air pressure, precipitation, layering soil temperature, soil moisture among others. These parameters were automatically obtained from instruments, and the instruments setup and data collection were operated by ANRMS. This station also has daily manual observation in snow depth and SWE. In this experiment, we requested the wind, air pressure, air wetness, soil temperature and moisture data during this experiment from ANRMS.

The red field was designed for automatic measurement of layering snow temperatures, snow density, SWE, snow depth, and albedo. These automatic measurement instruments were installed and maintained by NIEER, and started working from 2013. However, during the experiment, the instruments for snow density and SWE did not work, and we only collected layering snow temperatures and 4-component radiation from November 27, 2015 to March 25, 2016.

Because the four observation fields are located within the domain of the station and the distance between each other are less than $100 \mathrm{~m}$, the snow characteristics and soil and weather conditions are thought to be the same. Ultimately, the collected data in this study include ground-based brightness temperatures, 4-component radiation, snow pit data, meteorological data and automatically observed layering snow and soil temperatures.

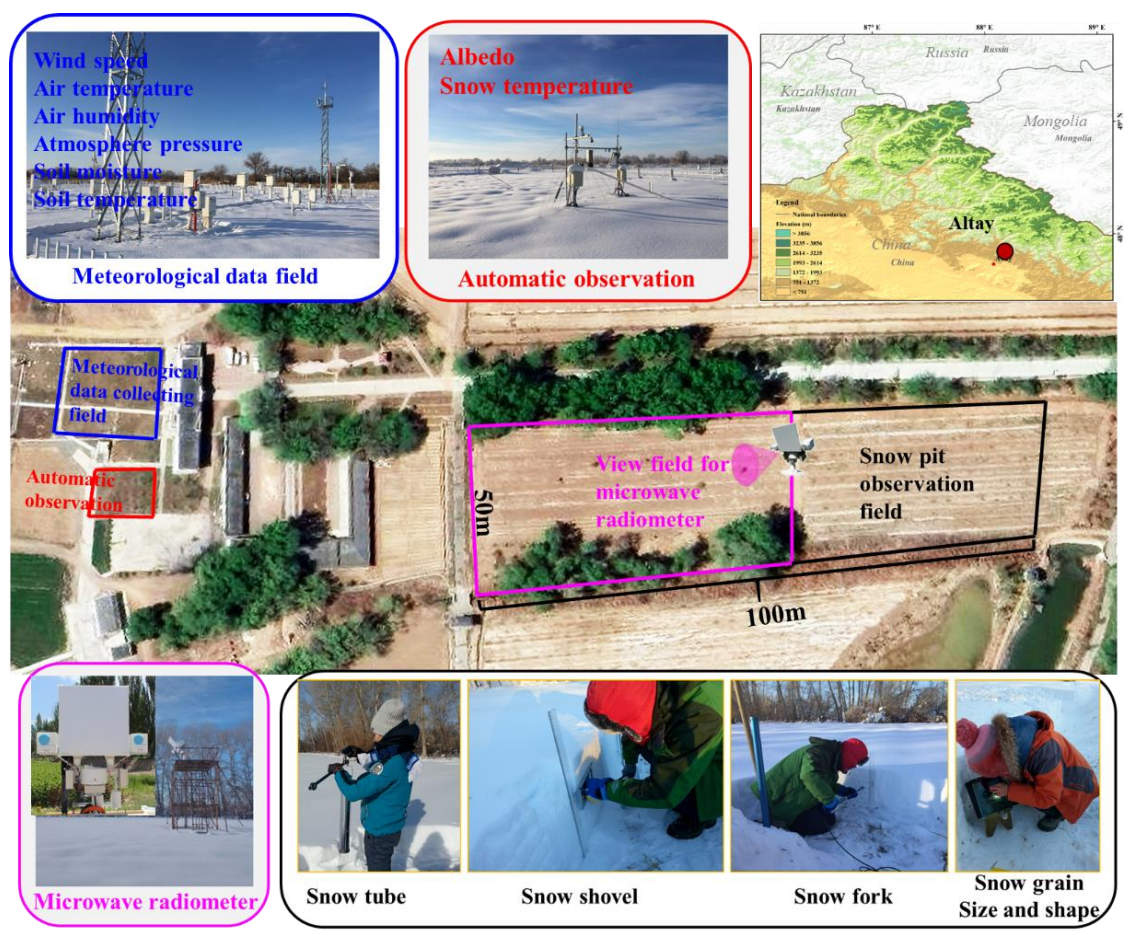



automatically observation of the snow temperature, SWE, 4-component radiation and snow depth, designed by Northwest Institute of Eco-Environment and Resources, Chinese Academy of Science (NIEER). Note: The map in the up right corner is ArcGIS self-contained map.

\subsection{Measurement parameters and instruments}

The brightness temperatures at 1.4, 18.6, $36.5 \mathrm{GHz}$ for both polarization $(\mathrm{Tb} 1 \mathrm{~h}, \mathrm{~Tb} 1 \mathrm{v}, \mathrm{Tb} 18 \mathrm{~h}, \mathrm{~Tb} 18 \mathrm{v}$, $\mathrm{Tb} 36 \mathrm{~h}, \mathrm{Tb36v}$ ) were automatically collected using a six-channel dual polarized microwave radiometer RPG-6CH-DP
(Radiometer
Physics
$\mathrm{GmbH}$,
Germany, https://www.radiometerphysics.de/products/microwave-remote-sensing-instruments/radiometers/). The technical specifications of the RPG-6CH-DP are described in Table 1. The RPG-6CH-DP contains a built-in temperature sensor which can measure air temperature. The automatically data collection frequency was set as 1 minute.

Table 1. Technical Specifications of the RPG-6CH -DP Microwave Radiometer.

\begin{tabular}{cc}
\hline \hline Parameter & Value \\
\hline Manufacturer & Radiometer Physics GmbH \\
System noise temperatures & $<900 \mathrm{~K}$ \\
Bandwidth & $400 \mathrm{MHz}(20 \mathrm{MHz}$ for $1.4 \mathrm{GHz})$ \\
System stability & $0.5 \mathrm{~K}$ \\
Dynamic range & $0 \sim 400 \mathrm{~K}$ \\
Frequencies (GHz) & $1.4,18.7,36.5$ \\
Polarizations & $\mathrm{V}, \mathrm{H}$ \\
Internal calibration & Internal Dicke switch and software control for \\
Receiver and antenna thermal stabilization & automatic sky tilt calibration \\
Antenna sidelobe level & $<0.015 \mathrm{~K}$ \\
Optical resolution (HPBW) & $<-30 \mathrm{dBc}$ \\
Incidence angle & $6.1^{\circ}\left(11^{\circ}\right.$ for $\left.1.4 \mathrm{GHz}\right)$ \\
Azimuth angle & $0 \sim 90^{\circ}$ \\
\end{tabular}

The microwave signatures from snowpack vary with snow characteristics, soil and weather conditions. The snow characteristics were obtained by manual snow pit measurements in the black field, including layering snow thickness, layering grain size, snow density, and snow temperatures. These data were daily collected during 8:00-10:00 am local time, from November 27, 2015 to March 25, 2016, except 7 days (please see Table 1). Although the snow temperatures were manually measured at snow pits, the automatically collected snow temperatures in the red field were utilized in this study, because the temperature measured at snow pits could not reflect the natural temperature profile when the snow pits exposed to the air. In the red field, the 4-component radiation was automatically measured by NR01 manufactured by Hukseflux, and layering snow temperatures was measured by Campbell 109S temperature sensors, respectively. The soil and weather parameters are of routine observations at 
172 ANRMS, and were obtained through request from ANRMS. The instruments used for soil and weather 173 parameters observations are produced by China Huayun Meteorological Technology Group corporation.

174 The measurement parameters and their measurement instruments are listed in table 2.

Table 2. Variables collected in MRESC and the observation equipment, observation time and frequencies.

\begin{tabular}{|c|c|c|c|c|}
\hline Parameter & Equipment/Method & Layering style & $\begin{array}{c}\text { Observation time } \\
\text { or frequency }\end{array}$ & Absent date \\
\hline $\begin{array}{l}\text { Tb1h, Tb1v, Tb18h, } \\
\text { Tb18v, Tb36h, Tb36v } \\
\text { and air temperature }\end{array}$ & $\begin{array}{c}\text { Microwave } \\
\text { radiometers RPG- } \\
6 \mathrm{CH}-\mathrm{DP} / \\
\text { Automatically }\end{array}$ & $\begin{array}{c}5 \text { meters above } \\
\text { ground }\end{array}$ & minutely & no \\
\hline Layer thickness $(\mathrm{cm})$ & Ruler / Manually & Natural layering & $\begin{array}{c}\text { local time 8:00- } \\
\text { 10:00 am }\end{array}$ & no \\
\hline Snow density $(\mathrm{g} / \mathrm{cm} 3)$ & Snow tube / Manually & Whole snowpack & $\begin{array}{c}\text { local time 8:00- } \\
\text { 10:01 am }\end{array}$ & no \\
\hline Snow density $(\mathrm{g} / \mathrm{cm} 3)$ & $\begin{array}{c}\text { Snow shovel/ } \\
\text { Manually }\end{array}$ & Every $10 \mathrm{~cm}$ & $\begin{array}{c}\text { local time 8:00- } \\
\text { 10:02 am }\end{array}$ & \\
\hline $\begin{array}{l}\text { Snow density }(\mathrm{g} / \mathrm{cm} 3) \\
\text { and liquid water content } \\
(\%)\end{array}$ & Snow fork/ Manually & $\begin{array}{l}\text { At interval of } 5 \\
\mathrm{~cm} \text { from the } 5-\mathrm{cm} \\
\text { height }\end{array}$ & $\begin{array}{c}\text { local time 8:00- } \\
\text { 10:03 am }\end{array}$ & $\begin{array}{l}1 / 2-3 / 2010, \\
2 / 20 / 2016\end{array}$ \\
\hline Snow grain size $(\mathrm{mm})$ & $\begin{array}{c}\text { Anyty V500IR/UV/ } \\
\text { Manually }\end{array}$ & Natural layering & $\begin{array}{c}\text { local time 8:00- } \\
\text { 10:04 am }\end{array}$ & $\begin{array}{c}\text { 12/24/2015, } \\
12 / 31 / 2015,1 /\end{array}$ \\
\hline Snow grain shape & $\begin{array}{c}\text { Visually } \\
\text { identification/ } \\
\text { Manually }\end{array}$ & Natural layering & $\begin{array}{c}\text { local time 8:00- } \\
\text { 10:05 am }\end{array}$ & $\begin{array}{c}1-3 / 2016,1 / 23 / \\
2016, \\
2 / 20 / 2016\end{array}$ \\
\hline Snow temperature $\left({ }^{\circ} \mathrm{C}\right)$ & $\begin{array}{c}\text { Temperature sensors } \\
\text { (Campbell 109S)/ } \\
\text { Automatically }\end{array}$ & $\begin{array}{c}0 \mathrm{~cm}, 5 \mathrm{~cm}, 10 \\
\mathrm{~cm}, 15 \mathrm{~cm}, 25 \mathrm{~cm}, \\
35 \mathrm{~cm}, 45 \mathrm{~cm} \text {, and } \\
55 \mathrm{~cm}\end{array}$ & Ten-minute & no \\
\hline $\begin{array}{l}\text { 4-component radiation } \\
\qquad(\mathrm{W} / \mathrm{m} 2)\end{array}$ & $\begin{array}{c}\text { Component Net } \\
\text { Radiometer (NR01) / } \\
\text { Automatically }\end{array}$ & $\begin{array}{l}6 \text { feets above } \\
\text { ground }\end{array}$ & Ten-minute & no \\
\hline Soil temperature $\left({ }^{\circ} \mathrm{C}\right)$ & $\begin{array}{l}\text { Soil temperature } \\
\text { sensor } \\
\text { (China Huayun) / } \\
\text { Automatically }\end{array}$ & $\begin{array}{c}5 \mathrm{~cm} \text { below } \\
\text { soil/snow surface } \\
\qquad(-5 \mathrm{~cm})\end{array}$ & Hourly & no \\
\hline Soil moisture $(\%)$ & $\begin{array}{l}\text { Soil moisture sensor } \\
\text { (DZN3, China } \\
\text { Huayun) / } \\
\text { Automatically }\end{array}$ & $\begin{array}{c}10 \mathrm{~cm} \text { below } \\
\text { soil } / \text { snow surface } \\
(-10 \mathrm{~cm})\end{array}$ & Hourly & no \\
\hline Air temperature $\left({ }^{\circ} \mathrm{C}\right)$ & $\begin{array}{c}\text { Thermometer screen } \\
\text { (China Huayun) / } \\
\text { Automatically }\end{array}$ & $\begin{array}{c}6 \text { feets above } \\
\text { ground }\end{array}$ & Hourly & no \\
\hline
\end{tabular}




\begin{tabular}{|c|c|c|c|c|}
\hline Air pressure $(\mathrm{Pa})$ & $\begin{array}{c}\text { Thermometer screen } \\
\text { (China Huayun) / } \\
\text { Automatically }\end{array}$ & $\begin{array}{l}6 \text { feets above } \\
\text { ground }\end{array}$ & Hourly & no \\
\hline Air humidity (\%) & $\begin{array}{c}\text { Thermometer } \\
\text { screen(China Huayun) } \\
\text { / Automatically }\end{array}$ & $\begin{array}{l}6 \text { feets above } \\
\text { ground }\end{array}$ & Hourly & no \\
\hline $\begin{array}{c}\text { Wind speed }(\mathrm{m} / \mathrm{s}) \text { and } \\
\text { direction }\end{array}$ & $\begin{array}{c}\text { Wind sensor(China } \\
\text { Huayun)/ } \\
\text { Automatically }\end{array}$ & $\begin{array}{l}10 \mathrm{~m} \text { above } \\
\text { ground }\end{array}$ & Hourly & no \\
\hline
\end{tabular}

\subsection{Measurement methods}

In this experiment, the measurements include microwave radiometry observation to collect brightness temperature, snow pit observation to collect snow physical parameters, automatic observation to collect 4-component radiation and snow temperatures, and meteorological observation which contains weather data and soil data.

\subsubsection{Microwave radiometry}

Before snow season, a platform with height of $5 \mathrm{~m}$, length of $4 \mathrm{~m}$ and width of $2 \mathrm{~m}$ was constructed in the experiment field. A 4-m orbit was fixed on the platform. The RPG-6CH-DP was set up on the orbit and could be moved along the orbit. This radiometer was sky tipping calibrated. In the clear sky conditions, the sky brightness temperatures are approximately $7.8 \pm 1 \mathrm{~K}$ and $15.7 \pm 0.7 \mathrm{~K}$ at $1.4 \mathrm{GHz}$ for horizontal polarization and vertical polarization, respectively; those were approximately $29.7 \pm 0.3 \mathrm{~K}$ and $29.3 \pm 0.9 \mathrm{~K}$ at $18.7 \mathrm{GHz}$ and $36.5 \mathrm{GHz}$, respectively.

Generally, the radiometers were fixed in the middle place of the orbit to observe snow cover with incidence angle of $45^{\circ}$. Multi-angle observations were conducted on seventeen days (Dec 3, Dec 19, Dec 30, Jan 3, Jan 8, Jan 13, Jan 18, Jan 23, Jan 28, Feb 3, Mar 3, Mar 10, Mar 15, Mar 22, Mar 26, Mar 28, Mar 31) when the radiometer was set to scan the ground at different incidence angles at two ends of the orbit and the middle place of the orbit. Although the view fields of the antennas for $1.4 \mathrm{GHz}, 18 \mathrm{GHz}$ and $36 \mathrm{GHz}$ did not completely overlap, the measured results showed that the brightness temperatures observed by radiometers at the left, middle and right of the orbit varied less than $1 \mathrm{~K}$. Therefore, the snow and soil characteristics presented homogeneous distribution within the view files of the three antennas.

\subsubsection{Snow pit measurement}

The physical snow parameters were measured at snow pits. These parameters included snow depth, snow density, snow layering, layering grain size and shape type, layering snow density.

The first step of snow pit measurement is making snow pit. In the black field, snow pits were made every day. A spade was used to excavate snow pit. The length of the snow pit profile was approximately $2 \mathrm{~m}$ to make sure all parameters were measured from unbroken snowpack. The width of the snow pit was approximately $1 \mathrm{~m}$ for observers to conveniently observe. The snow pit section was made as flat as possible using a flat shovel or ruler. When the snow profile expose to the air for a long time, the snow characteristics will be influenced by environment and will be different from the natural snow characteristics. In order to make sure every observation conducted on natural snow pit, the snow pit was 

day was made at least 1-m distance from the last snow pit.

The second step of snow pit measurement was recording the natural stratification. After finishing a snow pit, the natural stratification of snowpack was firstly visually determined against a ruler, and the snow thickness of every layer was recorded.

The third step was measuring grain size and shape type in each layer, whilst snow density was measured at constant interval. The grain size and type within each natural layer were estimated visually from a microscope with a camera named "Anyty V500IR/UV" (Figure 2a). A software matched the microscope was used to measure the grain size. The grain type was determined based on Fierz et al. (2009). In this experiment, we utilized the length of longest axes and the length of shortest axes to describe grain size (Figure 2b). When using the software to measure the grain size, a reference must be needed. In this experiment, the minimum scale " $0.5 \mathrm{~mm}$ " of a ruler was used as reference (Figure $2 \mathrm{c}$ ). We adjusted the focus of the camera to make sure the grains at the clearest status in camera to take photos, and the photo of ruler scale was taken at the same focus. If the thickness of one layer was less than 10 $\mathrm{cm}$, measurements were performed at the top and bottom of the layer. If the thickness was greater than $10 \mathrm{~cm}$, measurements were performed at the top, middle, and bottom of the layer. For each layer, at least 5 photos were taken, and at least 10 typical grains were chosen to measure the longest axes length and the shortest axes length in the photos of each layer. Then, in each layer, there were at least 10 groups of the longest and shortest axes length were obtained, and the final grain size was the average values. Figure A1 presents an example of the original photos of grains in each layer, and Table A1 shows the matched record of longest and shortest axis length.

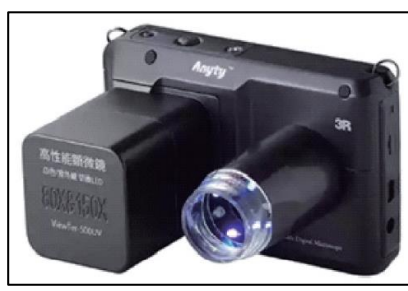

(a)

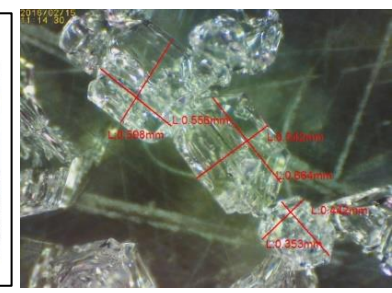

(b)

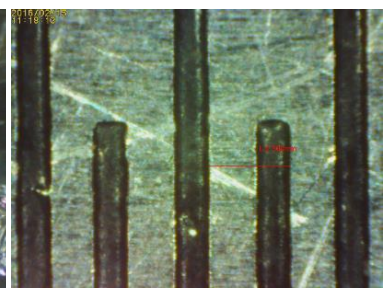

(c)

Figure 2: Picture of microscope "Anyty V500IR/UV" (a), the measured longest axes lengths and shorteast axes length of particles (b), and the reference ruler scale (c).

Snow density was measured using three instruments: snow tube, snow shovel and Snow Fork (Figure 3). The snow tube instrument, designed by Chinese Meteorological administration, contains a metal tube with the base area of $100 \mathrm{~cm}^{2}$ and the length of $60 \mathrm{~cm}$, and a balance (figure 3a). It was utilized to measure the snow density of a whole snowpack by weighing the snow sample. The snow shovel is a $1500 \mathrm{~cm}^{3}$ wedge-type sampler, and its length, width and height are $20 \mathrm{~cm}, 15 \mathrm{~cm}$, and $10 \mathrm{~cm}$, respectively (figure $3 b)$. It was utilized to measure layering snow density every $10 \mathrm{~cm}(0-10 \mathrm{~cm}, 10-20 \mathrm{~cm}, 20-30$ $\mathrm{cm} . .$.$) . The Snow Fork is a microwave resonator that measures the complex dielectric constant of snow,$ and adopts a semi-empirical equation to estimate snow density and liquid water content based on the complex dielectric. The Snow Fork (figure 3c) was utilized to measure snow density and liquid water content at $5-\mathrm{cm}$ intervals from the 5 - $\mathrm{cm}$ height over the snow/soil interface $(5 \mathrm{~cm}, 10 \mathrm{~cm}, 15 \mathrm{~cm}, 20 \mathrm{~cm} \ldots)$. Table A2 is an example of record table for snow density. Three times of observations were conducted for 


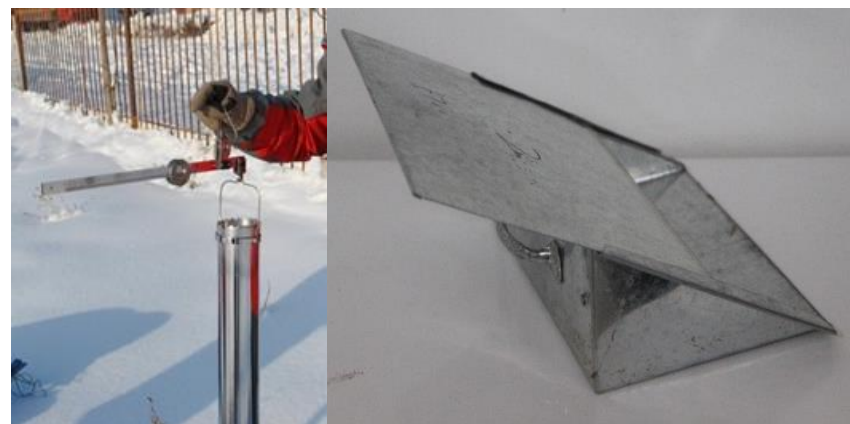

(a) (b)

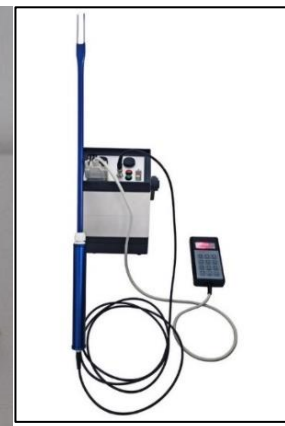

(c)

Figure 3: Three instruments for snow density: Snow tube (a), Snow shovel (b), and Snow Fork (c).

\subsubsection{Automatic radiation and temperature measurement}

Layering snow temperatures were collected using Temperature sensors at the red field instead of manual observation from snow pits. The temperature sensors had been set up on a vertical pole which was vertically inserted in the soil (Figure 4). The heights of the sensors are $0 \mathrm{~cm}, 5 \mathrm{~cm}, 10 \mathrm{~cm}, 15 \mathrm{~cm}$, $25 \mathrm{~cm}, 35 \mathrm{~cm}, 45 \mathrm{~cm}$, and $55 \mathrm{~cm}$. The snow temperatures at these heights were collected every minute.

TheNR01 net radiometer was set up to measure the energy balance between incoming short-wave and long-wave Far Infrared radiation versus surface-reflected short-wave and outgoing long-wave radiation. The range of short wave is $285 \sim 3000 \mathrm{~nm}$, and the range of long wave is $4.5 \sim 40 \mathrm{um}$. The 4component radiation was automatically recorded every ten minutes. In addition, the sensor is equipped 


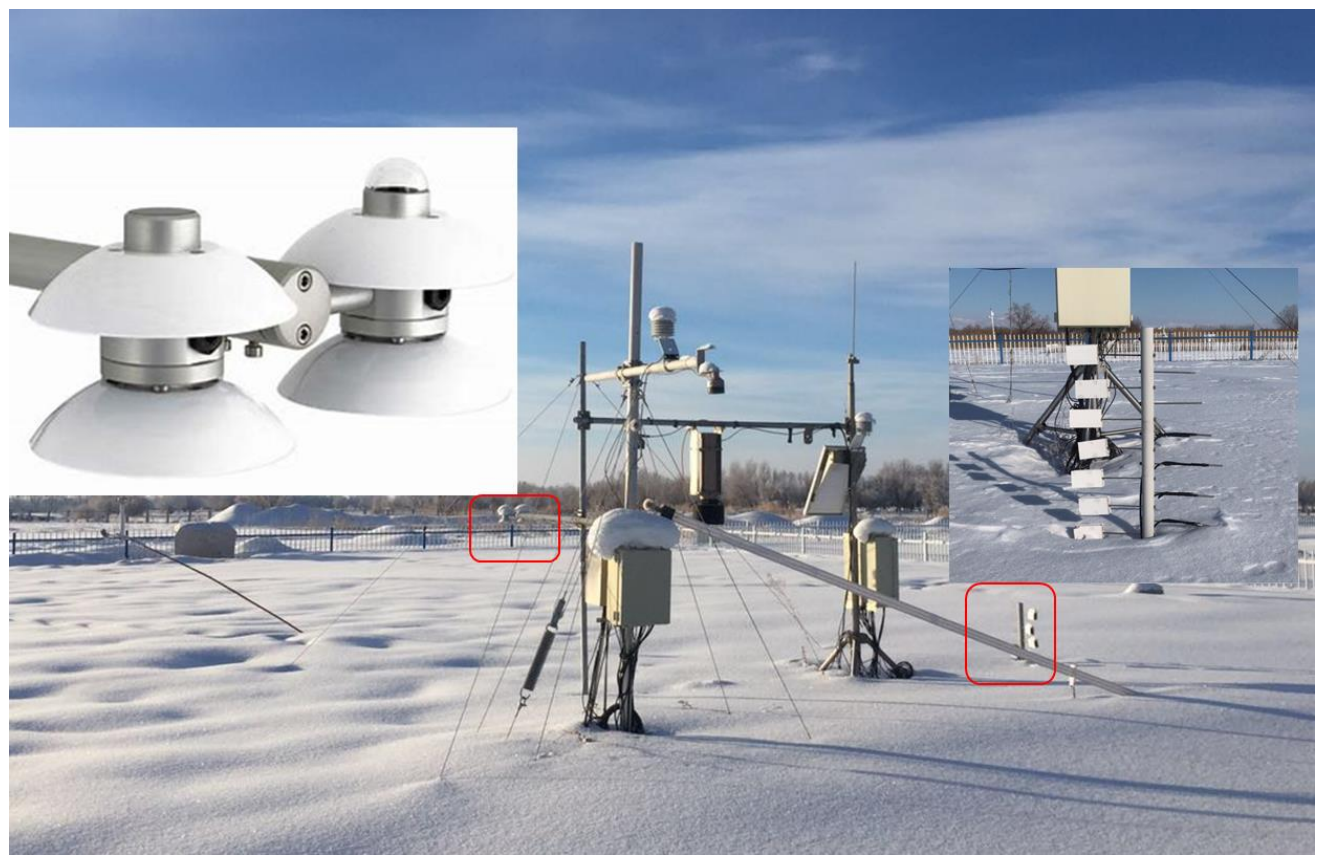

Figure 4: Set up of temperature sensors and CNR4 in the red field.

\subsubsection{Meteorological observation}

The meteorological data requested from the ANRMS include air temperature, air pressure and humidity, wind speed, soil temperature at $-5 \mathrm{~cm},-10 \mathrm{~cm},-15 \mathrm{~cm}$ and $-20 \mathrm{~cm}$ and soil moisture at $-10 \mathrm{~cm}$ and $-20 \mathrm{~cm}$.

The air temperature, pressure and humidity were collected using temperature and wetness sensor in thermometer screen, the wind speed and direction were measured using wind sensor set up at $10 \mathrm{~m}$ on a tower. Soil moisture and temperature were automatically measured using moisture sensor and temperature sensor. Figure 5 depicts the instruments for these observations.

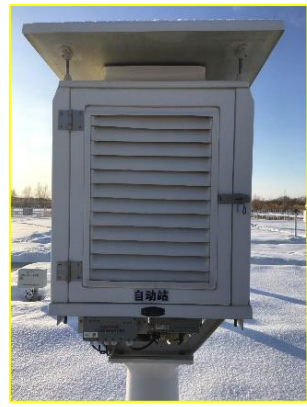

(a)

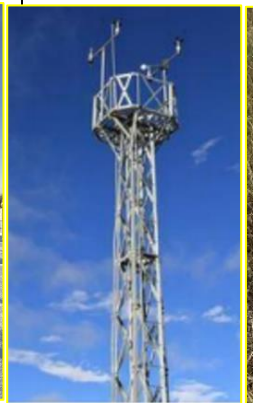

(b)

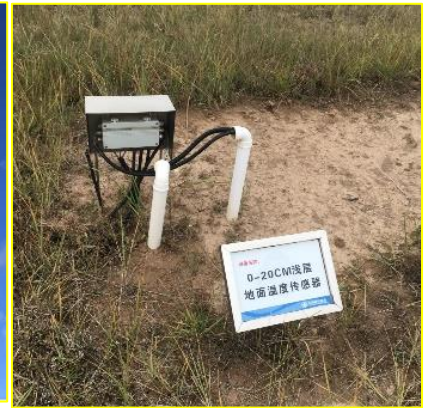

(c)

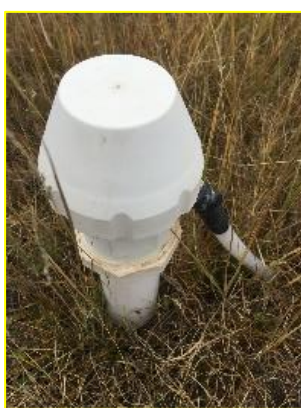

(d)

Figure 5: Instruments for observation of air temperature and wetness (a), wind speed (b), soil temperature (c) and soil moisture (d). 


\section{Description of consolidated IMCS data}

The microwave brightness temperature, snow parameters, meteorological data were recorded in different formats, and the observation frequencies and times were different. These data must be reorganized or consolidated for easily usage. The values from the three-time measurements for snow density in each layer were averaged to obtain the final snow density. The length of the longest and shortest axes of particles in each photo were measured using the software. The average lengths of longest and shortest axes from all photos in each layer were obtained as the final grain size.

The ground-based brightness temperatures and layering snow temperatures were automatically collected in uniform format. The weather and soil data requested from ANRMS had been consolidated. Finally, the provided datasets are as following and table 3 describes the contents of each dataset.

\section{1) Brightness temperatures data:}

1 Minutely calibrated brightness temperature at $1.4 \mathrm{GHz}, 18 \mathrm{GHz}$ and $36 \mathrm{GHz}$ for both polarizations at incidence angle of $45^{\circ}$. This data include date, time, brightness temperatures at the three bands for both polarizations.

2 Seventeen groups of calibrated brightness temperature at $1.4 \mathrm{GHz}, 18 \mathrm{GHz}$ and $36 \mathrm{GHz}$ for both polarizations at different incidence angles $\left(30,35,40,45,50,55,60^{\circ}\right)$. This data include date, incidence angles, brightness temperatures at the three bands for both polarizations.

\section{2) Snow pit data:}

1 Daily grain size data include date, snow depth, layering snow thickness, average longest axis, average shortest axis of each layer. The data were stored in an excel sheet.

2 Daily snow density data include date, layering snow density using snow fork (snow density at different heights, such as SF_5 cm, SF_10 cm, SF_15cm), snow density using snow tube, layering snow density using snow shovel (such as SS_0-10cm, SS _ 10-20cm, SS _ 20-30cm, SS _ 30-40cm). The data were stored in an excel sheet.

3 Ten-minute snow temperatures data include date, time, temperatures at different heights (such as ST_0cm, ST_5cm).

\section{3) Snow surface radiation data}

14 -component radiation data include date, time, short-wave incident radiation, short-wave reflected radiation, long-wave infrared incident radiation, long-wave infrared reflected radiation, and sensor temperature.

\section{4) Meteorological data:}

1 Hourly weather data include date, hour, air temperature, wetness and humidity wind speed and direction. 2 Hourly Soil data include date, hour, soil temperature at $5 \mathrm{~cm}, 10 \mathrm{~cm}, 15 \mathrm{~cm}$ and $20 \mathrm{~cm}$, and soil moisture at $10 \mathrm{~cm}$ and $20 \mathrm{~cm}$.

These data were stored in four folders, and different parameters were stored in different excel table or ascii files. The organization of these consolidated data were described in table 3 .

\begin{tabular}{llll}
\hline \hline Folder & Data & Store format & Content \\
\hline $\begin{array}{l}\text { Brightness } \\
\text { temperature }\end{array}$ & $\begin{array}{l}\text { Minutely brightness } \\
\text { temperature }\end{array}$ & Ascii file & Date, time, Tb1h, Tb1v, Tb18h, Tb18v, Tb36h, Tb36v \\
\hline
\end{tabular}




\begin{tabular}{|c|c|c|c|}
\hline & $\begin{array}{l}\text { Multi-angle } \\
\text { brightness } \\
\text { temperatures }\end{array}$ & Ascii file & $\begin{array}{l}\text { Date, time, incidence angle, Tb1h, Tb1v, Tb18h, Tb18v, } \\
\text { Tb36h, Tb36v }\end{array}$ \\
\hline \multirow{3}{*}{ Snow pit data } & Grain size & Excel sheet & $\begin{array}{l}\text { Date, snow depth, th1, Lg1, Sg1, th2, Lg2, Sg2,th3, Lg3, } \\
\text { Sg3, th4, Lg4, Sg4,th5, Lg5, Sg5, th6, Lg6, Sg6 }\end{array}$ \\
\hline & Snow density & Excel sheet & $\begin{array}{l}\text { Date, Stube, SS_0-10, SS_10-20, SS_20-30, SS_30-40, } \\
\text { SS_40-50, SF_5, SF_10, SF_15, SF_20, } \\
\text { SF_25,SF_30,SF_35,SF_40,SF_45,SF_50, }\end{array}$ \\
\hline & Snow temperature & Excel sheet & $\begin{array}{l}\text { Date, time, snow depth, ST_0cm, ST_5cm, ST_15cm, } \\
\text { ST_25cm, ST_35cm, ST_45cm, ST_55cm }\end{array}$ \\
\hline Radiation data & $\begin{array}{l}\text { 4-component } \\
\text { radiation }\end{array}$ & Excel sheet & $\begin{array}{l}\text { Date, time, SR_DOWN, SR_UP, LR_DOWN, LR_UP, } \\
\text { T_Sensor }\end{array}$ \\
\hline \multirow{2}{*}{$\begin{array}{l}\text { Meteorological } \\
\text { data }\end{array}$} & Hourly weather data & Excel sheet & Date, hour, Tair, Wair, Pair, Win \\
\hline & $\begin{array}{l}\text { Hourly soil moisture } \\
\text { and temperature }\end{array}$ & Excel sheet & $\begin{array}{l}\text { Date, SM_10cm, SM_20cm, Tsoil_5cm, Tsoil_10cm, } \\
\text { Tsoil_15 cm, Tsoil_20cm }\end{array}$ \\
\hline
\end{tabular}

317 Note: th: snow thickness, Lg: long axis, Sg: short axis;

318 Stube: snow density observed using snow tube, SS: snow density observed using snow shovel, SF: snow density observed using snow fork; ST: snow temperature; SR_DOWN: downward short-wave radiation, SR_UP: upward short-wave radiation, LR_DOWN, downward long-wave radiation, LR_UP: upward long-wave radiation, T_sensor: sensor temperature; Tair: air temperature, Wair: air wetness, Pair: air pressure, Win: wind speed.

\subsection{Snow characteristics}

\subsubsection{Layering grain size and grain shape}

During winter of 2015/2016, snow cover began on 25 November of 2015, and ended on March 25 of 2016. During this snow cover duration, seven snowfall events occurred, and each snowfall formed one layer in snow cover on the ground, except the third event which presented a new layer on the second layer at the beginning, but the layering interface disappeared after several days and visually displayed as one layer (in gray in Figure 6). The fourth event was biggest of all, and the depth of snow cover exhibited decreasing with increase of snow density after the fourth event. Snow cover began melting on March 14 and snow depth declined to zero within 10 days.

Grain sizes within all layers exhibited increasing during the snow season, except in the bottom layer where grain size experienced a decrease from December 28 to January 20 (Figure 7). In the vertical profile, grain size increased from up to down with the snow age. The grain size of the fresh snow was approximately $0.3 \mathrm{~mm}$. The biggest long and short axis were up to $6 \mathrm{~cm}$ and $4 \mathrm{~cm}$, respectively, which occurred within Layer 1 in the melting period. The length of short axes is approximately 0.7 of the length of long axes. The grain shape generally developed from rounded grains to facet crystals, and then to depth hoar. After March 13, 2016, the minimum air temperature increased to above 0, snowpacke accelerately melted, and the grain shape developed to melted forms. 
$\square$ Rounded grains and depth hoar $\quad \square$ Rounded grains and faceted crystals $\quad \square$ Faceted crystals and depth hoar $\quad \square$ Faceted crystals and surface hoar

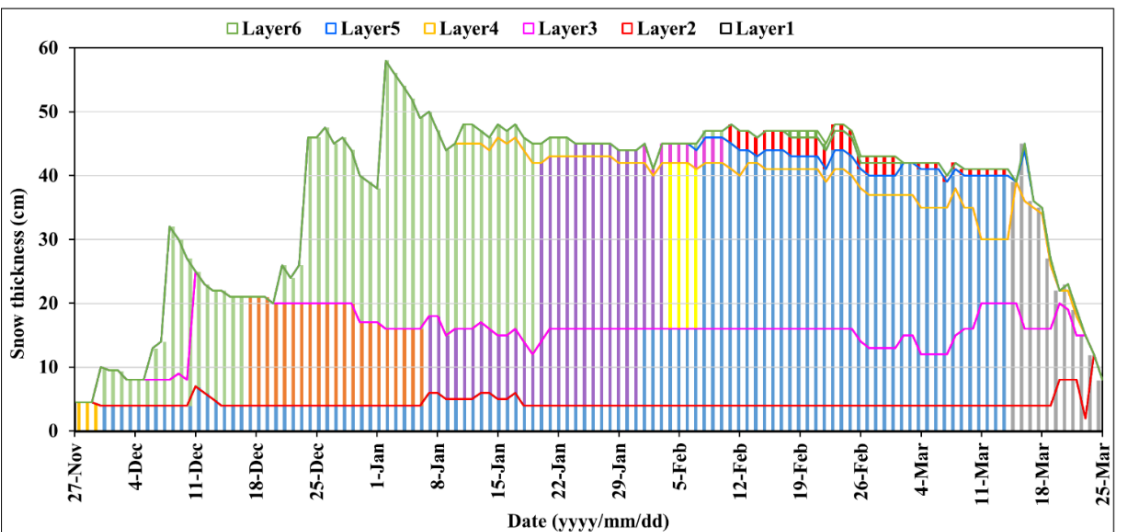

Figure 6: Daily variation in layering grain shape from November 27, 2015 to March 25, 2016.
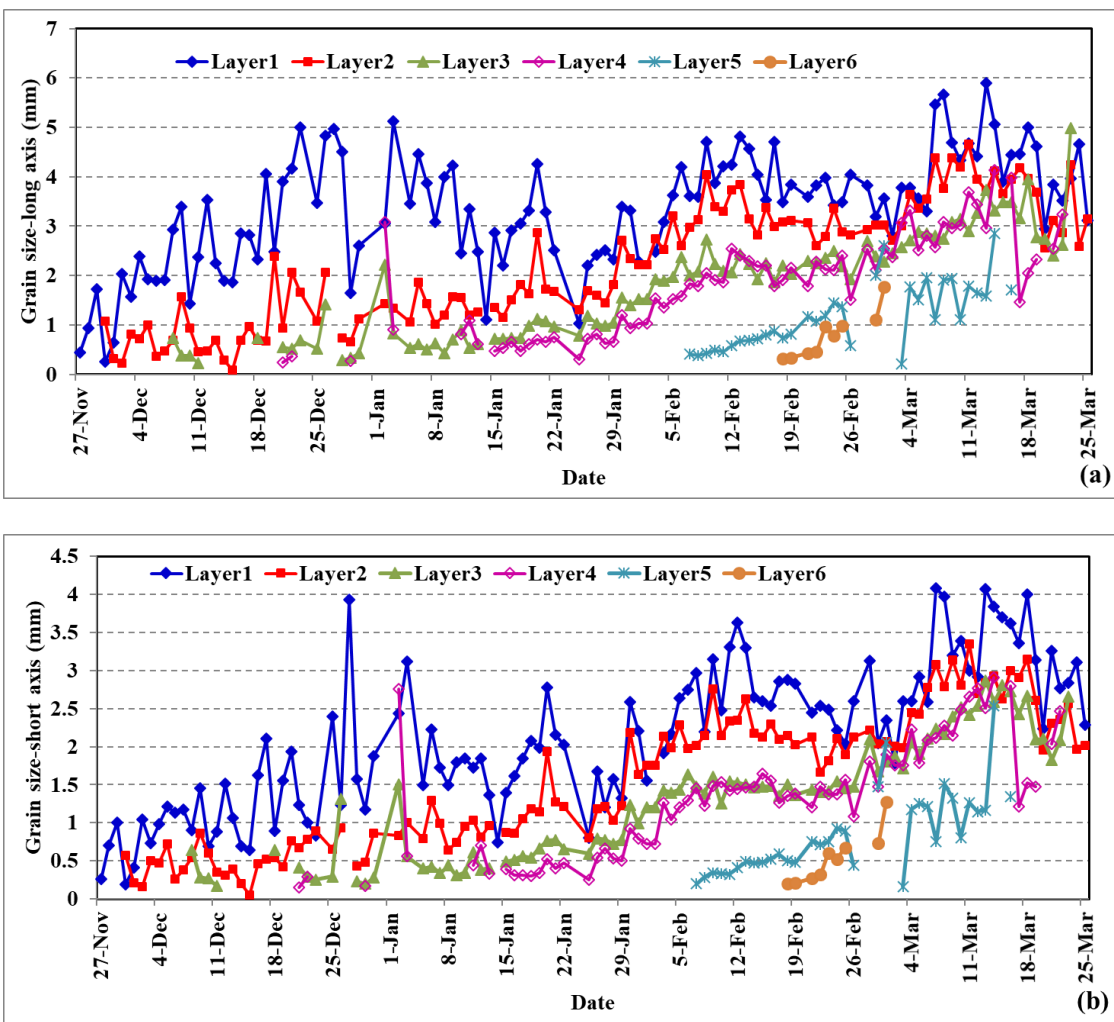

Figure 7: Daily variation in grain size within each layer from November 27, 2015 to March 25, 2016. The thickness of each layer is presented in figure 9.

Snow densities measured by three different equipment shows that the density of fresh snow ranged 

the value arrived at $0.2 \sim 0.25 \mathrm{~g} / \mathrm{cm} 3$. From March 14 on, snow densities abruptly increased. The biggest value was beyond $0.45 \mathrm{~g} / \mathrm{cm} 3$. In the vertical profile, snow density increased from up to down in the accumulation phase, but in the stable phase, snow densities in the middle layers were larger than those in the bottom and upper layers. In the melting phase, snow densities in all layers showed little difference.
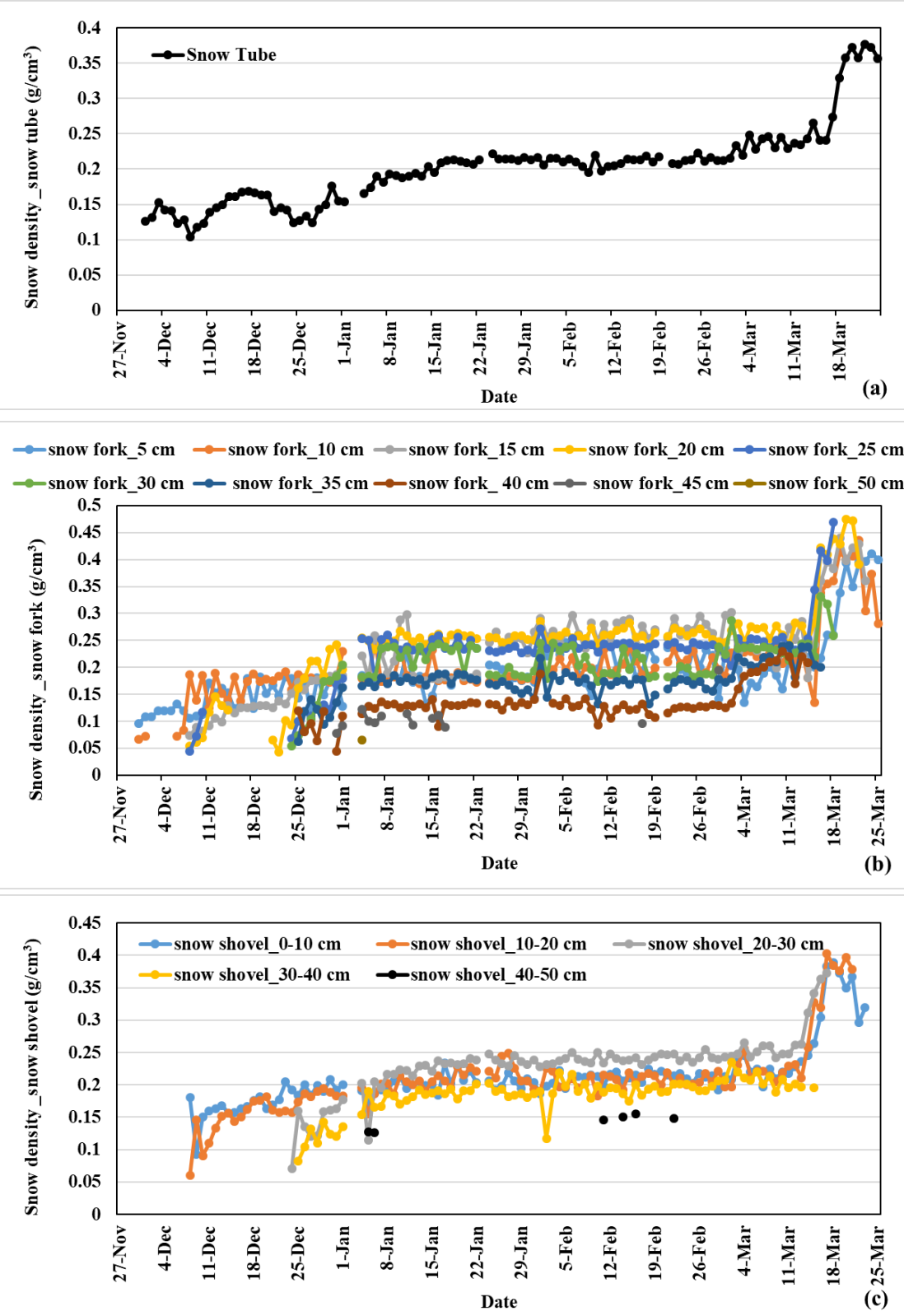

Figure 8: Daily variation in snow densities measured using three different measurement methods from 


\subsubsection{Snow temperature}

Snow temperature at $0 \mathrm{~cm}$ (snow/soil interface temperature) showed little diurnal variation, remaining at approximately -2.0 to $0.7^{\circ} \mathrm{C}$. Snow temperature at top layer exhibited largest diurnal variation. The diurnal variation range decreased from top to bottom layers, and with the increase of snow depth, temperatures in more layers presented small diurnal variations (Figure 9). After March 17, 2016, the snow temperature of all layers were over $0^{\circ} \mathrm{C}$ which means snow cover did not refreeze anymore.

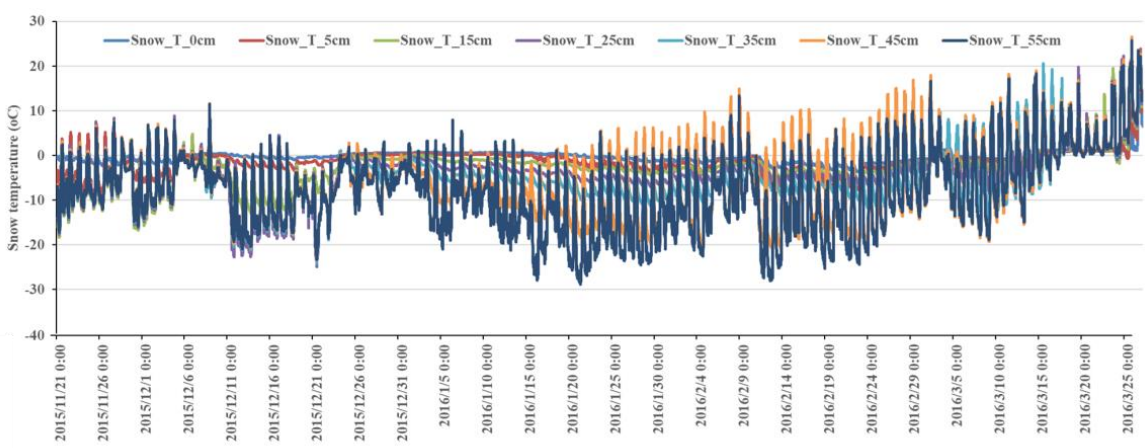

Figure 9: Variation in layering snow temperatures during experiment time.

\subsection{Soil temperature and moisture}

The soil temperature at 5 and $10 \mathrm{~cm}$ remained below $0{ }^{\circ} \mathrm{C}$ and stable during the snow season, but presented large fluctuation before snow cover onset and after snow off (Figure 10). The temperature gaps between $5 \mathrm{~cm}$ and $10 \mathrm{~cm}$ were much larger before snow cover onset than those during snow cover duration. The soil moistures at $10 \mathrm{~cm}$ were above $10 \%$ before snow cover onset and after snow off, and were below 10\% during the snow cover duration. During Dec 12-14, and Jan 1- 20, soil moisture showed peak value, which corresponded to the two high-value periods of soil temperature.

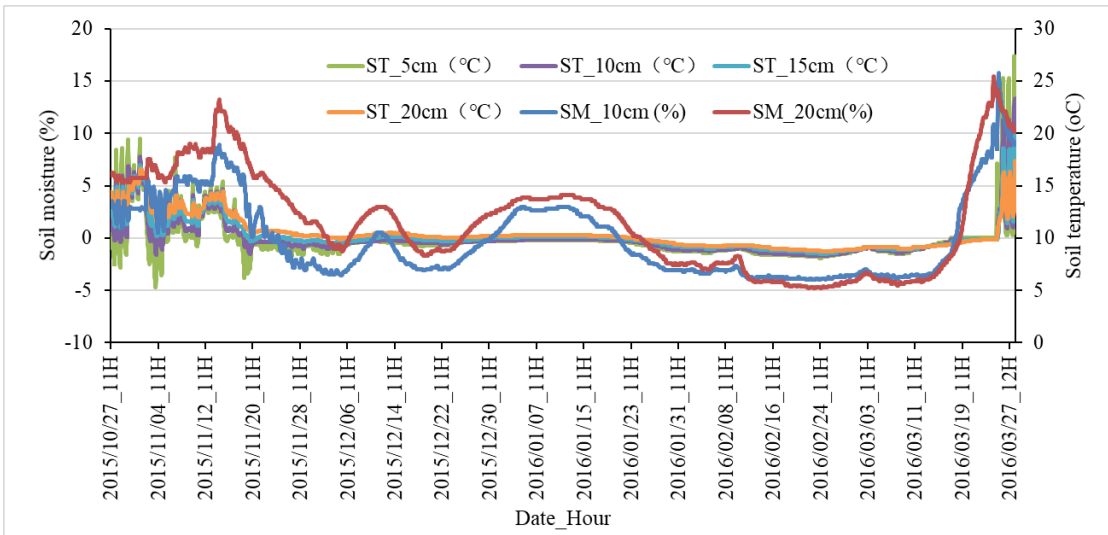

Figure 10: Hourly variation in soil temperature at $5 \mathrm{~cm}, 10 \mathrm{~cm}, 15 \mathrm{~cm}$ and $20 \mathrm{~cm}$, and soil moisture at $10 \mathrm{~cm}$ and $20 \mathrm{~cm}$. 


\subsection{Brightness temperature}

The microwave brightness temperatures varied with snow and soil characteristics, and weather conditions. Figure 11a shows the daily brightness temperatures, brightness temperature difference between 18 and $36 \mathrm{GHz}$, snow depth and air temperature at 1:00 am, and Figure 11b shows the hourly variation in brightness temperatures at the three frequencies and air temperature after February 1. Data depict that $\mathrm{Tb} 36 \mathrm{~h}$ and $\mathrm{Tb} 36 \mathrm{v}$ decreased during the whole snow season, Tb18h show obvious decline after Feb 18, and Tb18v show decline after Mar 3 for vertical polarization (Figure 11a). After Jan 4, snow depth stopped increasing, but the brightness temperature continued to decrease and brightness temperature difference increased. Based on Figure 8, snow density arrived at stable on Jan 15. Therefore, after Jan 4 , the decreasing brightness temperatures was mainly caused by growing grain size.

After Feb 25, brightness temperature exhibited abrupt increase (at day time) - decrease (at night time) circle (Figure 11b), because air temperature at noon increasing up to above $270 \mathrm{~K}$ resulted in large liquid water content at day time, and the melted snowpack refroze when air temperature decreased at night time and brightness temperature decreased. After March 14, air temperature presented another big rise and even the night air temperatures were above $270 \mathrm{~K}$; snow cover accelerated melting, and the liquid water could not be completely refrozen; then brightness temperature and brightness temperature difference exhibited unregularly variations.

The variation of $\mathrm{L}$ band was mainly influenced by soil moisture and soil temperature. We have soil temperatures at $0 \mathrm{~cm}, 5 \mathrm{~cm}$ and $10 \mathrm{~cm}$ and soil moisture at $10 \mathrm{~cm}$. However, the L band reflects the soil moisture within $5 \mathrm{~cm}$ which was absent in this experiment. Actually, we did not find the variation of brightness temperature at $\mathrm{L}$ band had relationship with soil moisture at $10 \mathrm{~cm}$ and soil temperature.

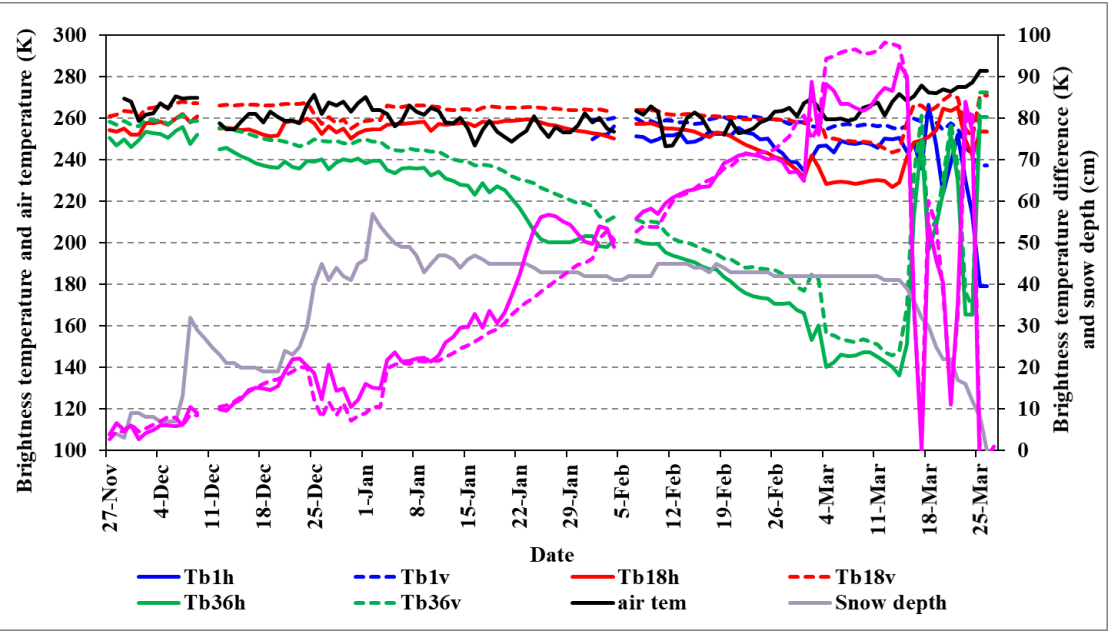




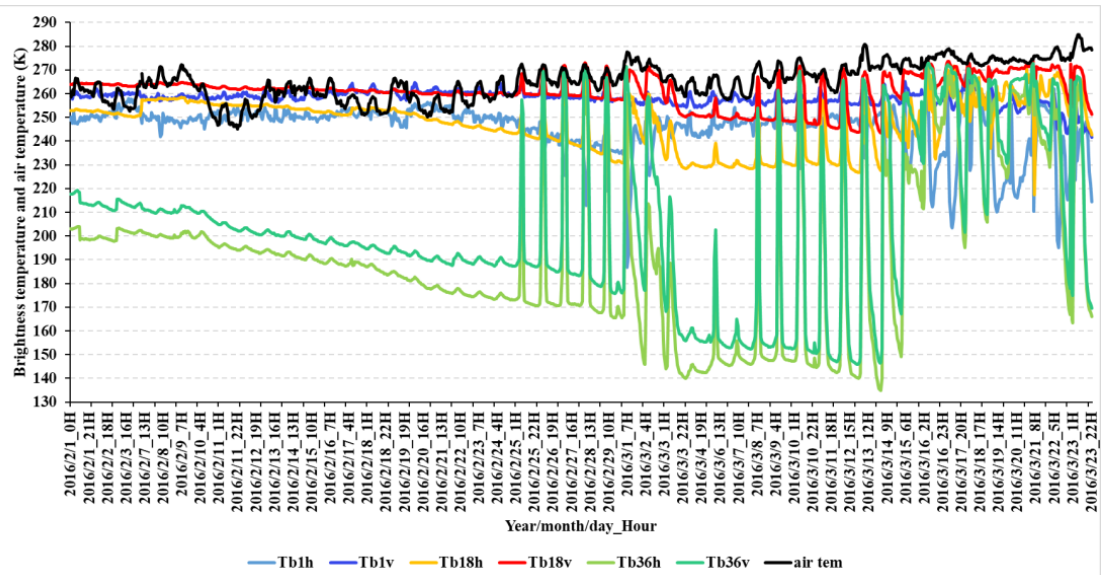

Figure 11: (a) Daily variations in brightness temperatures at $1.4 \mathrm{GHz}, 18 \mathrm{GHz}$ and $36 \mathrm{GHz}$, for horizontal (Tb1h, Tb18h, Tb36h) and vertical polarizations (Tb1v, Tb18v, Tb36v), and the differences between Tb18h and Tb36h (TBDh), and between Tb18v and Tb36v (TBDv), at 1:00 am (local time), from November 27, 2015 to March 26, 2016. (b) hourly variation in Tb1h, Tb18h, Tb36h, Tb1v, Tb18v, Tb36v, from February 1 to March 23, 2016.

The brightness temperatures from AMSR-2 were compared with the ground-based observation at the overpass time (Figure 12). Although there was large difference between them, the general variations are the same, even for the abrupt change between Mar 3 and Mar 4, and the correlation coefficients at both polarizations were approximately 0.96 and 0.7 for $36 \mathrm{GHz}$ and $18.7 \mathrm{GHz}$, respectively. Satellite observed brightness temperature presented less decrease trend than ground-based observation, and the difference at $36 \mathrm{GHz}$ is larger than at $18 \mathrm{GHz}$ (Figure 12). The difference between ground-based and satellite observation might be attributed to the different viewing area.

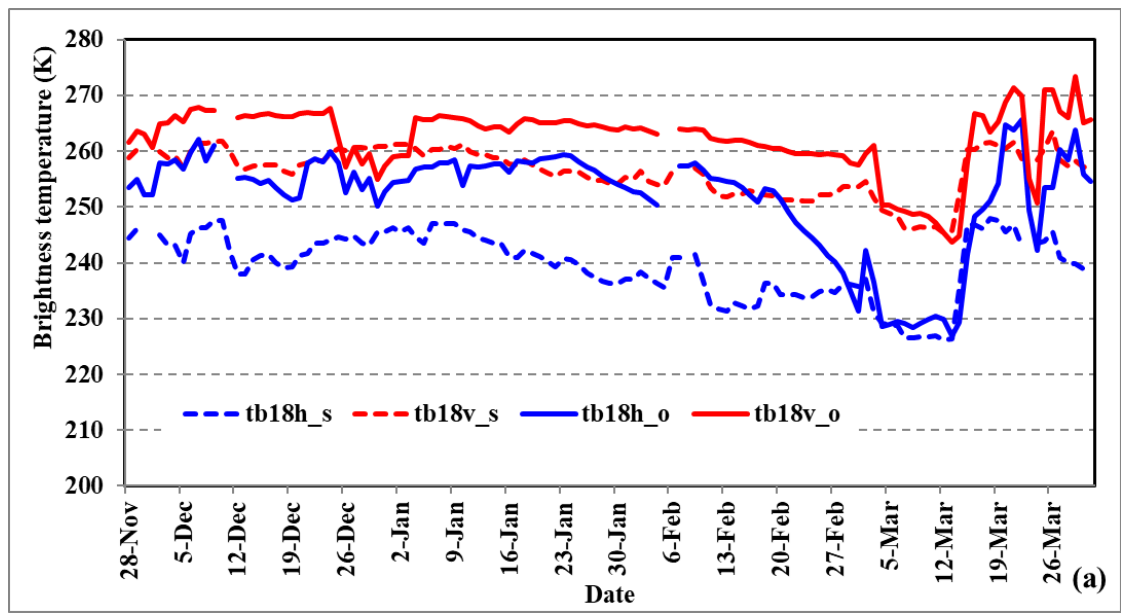




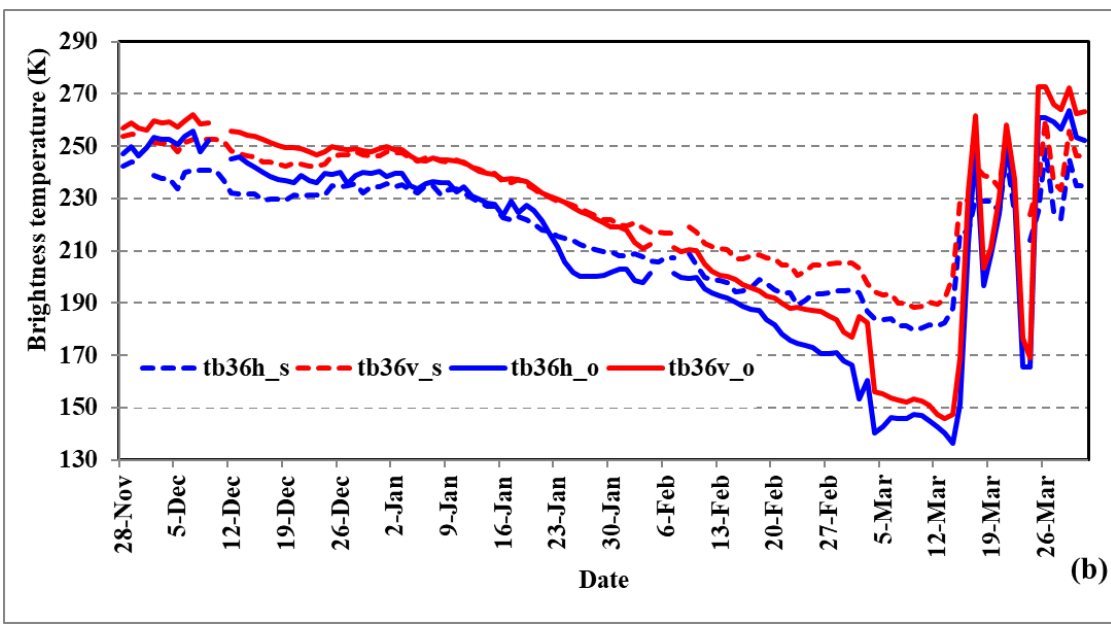

Figure 12: Comparison of brightness temperature between ground-based and Satellite-based observation (s: satellite; o: observation), (a) for $18 \mathrm{GHz}$, (b) for $36 \mathrm{GHz}$.

\subsection{4-component Radiation}

The land surface albedo is strongly related to the land cover. In this experiment, the down-short wave radiation presented general increase after January, and the trend became distinctive after February (Figure 13). The upward short-wave radiation abruptly increased when the ground was covered by snow, and sharply declined on the snow off day. From the first snowfall to the end of January, the ratios between upward and downward short-wave radiation were approximately $95 \%$. The ratio decreased with snow age, and in the end of snow season the ratios decreased to below $50 \%$ because of increasing melted water.

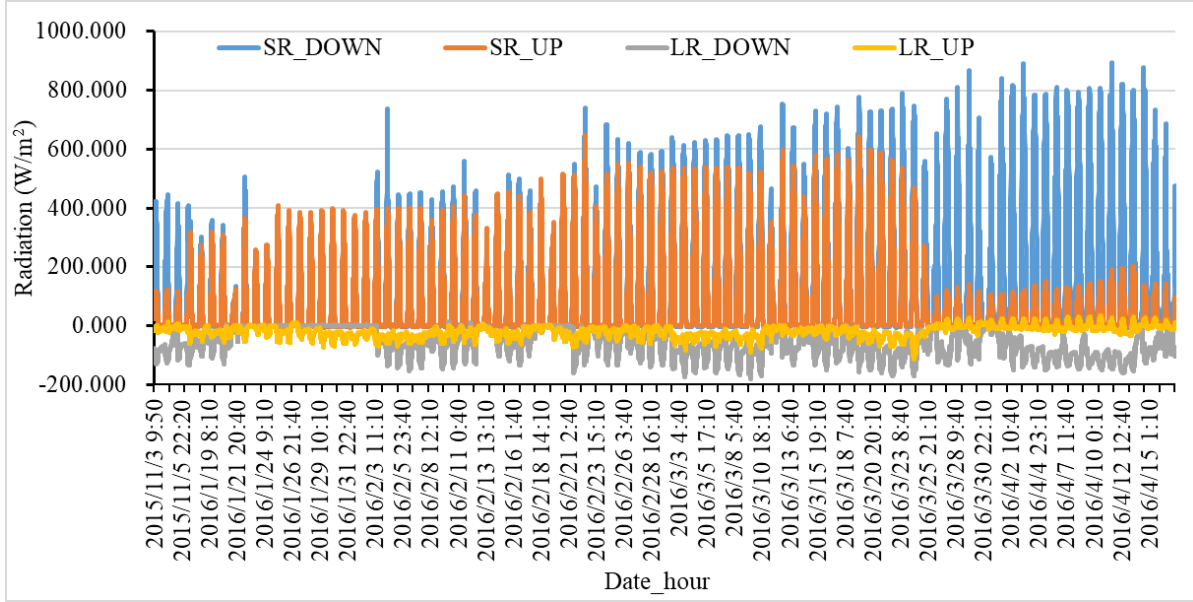

Figure 13: Minutely variation in 4-component radiation at Altay station from November 32015 to April 15 2016. 


\section{Discussion}

This experiment provided a suite of snow characteristics and microwave brightness temperatures, and have proven useful for evaluating and updating microwave emission transfer model of snowpack (Dai et al., 2021). This dataset reflected the general fact that brightness temperature at higher frequencies presented stronger volume scattering of snow grains, and were more sensitive to snow characteristics. This experiment revealed that the dominant control factor for the variation of brightness temperature was the variation of grain size but not the snow depth. The largest snow depth or SWE does not correspond to the largest brightness temperature gradient in the condition of dry snowpack. Due to the growth of grain size, the peak gradient occurred before melting for stable snow cover. Therefore, the daily snow depth variations curve derived from passive microwave remote sensing datasets tend to exhibit a temporal offset from those of in situ observation.

During the snow season, brightness temperatures for both polarizations presented similar variation, but they behaved different in some temporal periods. The horizontal polarization was more sensitive to environment and demonstrated less stable than vertical polarization. Besides, the polarization difference at $18 \mathrm{GHz}$ and $36 \mathrm{GHz}$ showed increase and decrease trends, respectively during the experimental period. The results for $18 \mathrm{GHz}$ were opposite to the simulation results (Dai et al., 2021). These phenomena must rely on the environmental conditions, snow characteristics and soil conditions. However, the subsurface soil wetness data were absent, the dynamic ground emissivity could not be estimated. L band has strong penetrability, and the brightness temperature variations were dominantly related to subsurface soil condition, except when the liquid water content within snowpack was high. Therefore, although we did not have soil moisture data in the subsurface layer, $\mathrm{L}$ band brightness temperatures were expected to retrieve soil moisture variation which influence the soil transmissivity (Babaeian et al., 2019; Naderpour et al., 2017; Hirahara et al., 2020).

Snow surface albedo significantly influence the incoming solar radiation, playing an important role in climate system. The factors to change the snow surface albedo essentially contains the snow characteristics (grain size, SWE, liquid water content, impurities, surface temperature etc), external atmospheric condition and solar zenith angle (Aoki et al., 2003). Snow albedo was estimated based on snow surface temperatures in some models (Roesch et al., 1999), and some models considered snow surface albedo mainly depends on snow aging (Mabuchi et al., 1997). In this experiment, we obtained the 4-component radiation, snow pit and meteorological data. These data provide nearly all observations of possible influence factors, and could be utilized to discuss and analyze shortwave radiation process of snowpack, and validate or improve multiple-snow-layer albedo model.

Snow grain sizes and snow densities within different layers presented different growth rates at different temporal phase. Generally, the growth rates are related to the air temperature, pressure and snow depth (Chen et al., 2020; Essery, 2015; Vionnet et al., 2012; Lehning et al., 2002); therefore, this dataset can be used to analyze the evolution process of snow characteristics, as well as validation data for snow models.

\section{Conclusions}

In a summary, the IMCS campaign provides a time series of snow pits observation, meteorological parameters, optical radiation and passive microwave brightness temperatures in the whole snow season of $2015 / 2016$. The dataset is unique in providing microwave brightness temperatures and matched daily 
snow pits data over a snow season at the fix site.

The dataset contains the unique daily snow pit data which present detail description of snow grain size, snow density and snow temperature profiles. It can be used to analyzes the evolution process of snow characteristics, validating or improving the snow process models, such as SNOWPACK (Lehning et al., 2002), SNTHERM (Chen et al., 2020). The improvement of these models can further enhance the prediction accuracy of land surface process and hydrology models, and the simulation accuracy of snow microwave emission models.

Actually, this dataset has been utilized to analyze the volume scattering features of snow pack at different frequencies (Dai et al., 2021). It can also be used to further analyze polarization characteristics of snow pack, and be used to validate different microwave emission models of snowpack.

Moreover, in this experiment, the microwave and optical radiations were simultaneously observed. The existing studies reported that the optical equivalent diameter must be used in microwave emission model with caution (Lowe and Picard, 2015; Roy et al., 2013). It is a good chance to analyze the difference between the influence of grain size on microwave and optical radiation, establishing the bridge between effective optical grain size and microwave grain size.

\section{Data availability}

The IMCS consolidated datasets are available after registration on the National Tibetan Plateau Data Center and available online at https://data.tpdc.ac.cn/en/ (doi: 10.11888/Snow.tpdc.270886). Microwave radiometry raw Data are available for scientific use on request from Northwest Institute of EcoEnvironment and Resources, Chinese Academy of Sciences.

Author contributions: LD and TC designed the experiment. LD, YZ, JT, MA, LX, SZ, YY YH and LX collected the passive microwave and snow pit data. HL provided the 4-component radiation and snow temperature data. LW provided meteorological data. LD write the manuscript, and TC made revision. All authors contributed to the data consolidation.

Competing interests: The authors declare that they have no conflict of interest.

Acknowledgment: The authors would like to thank the Altay meteorological station for providing logistics service and meteorological data.

Financial support: This research was funded by the National Science Fund for Distinguished Young Scholars (grant nos: 42125604), National Natural Science Foundation of China (grant nos: 42171143), and CAS 'Light of West China' Program. 


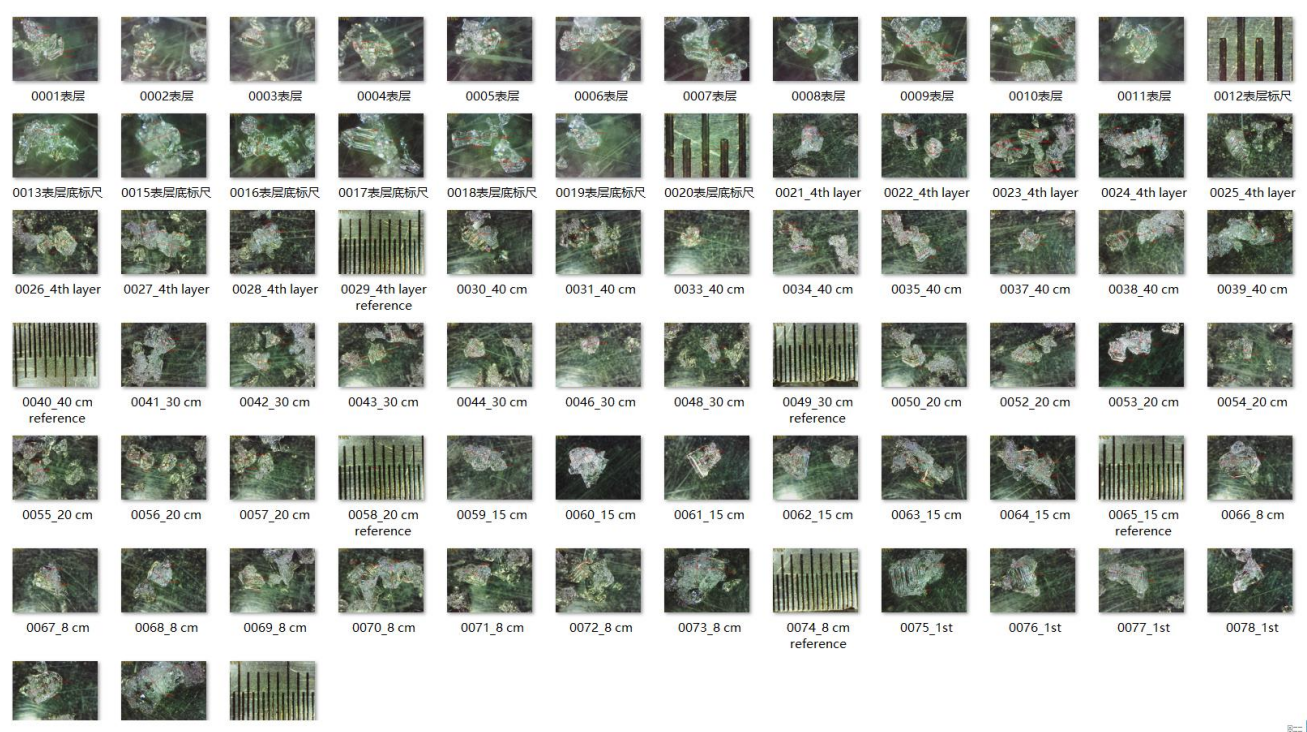

Figure A1: Photos of grains and reference ruler in each layer on February 15, 2016, and in each photo the longest and shortest axis lengths of the chosen grains are labeled.

Table A1. Recorded longest and shortest axis length in Figure A.

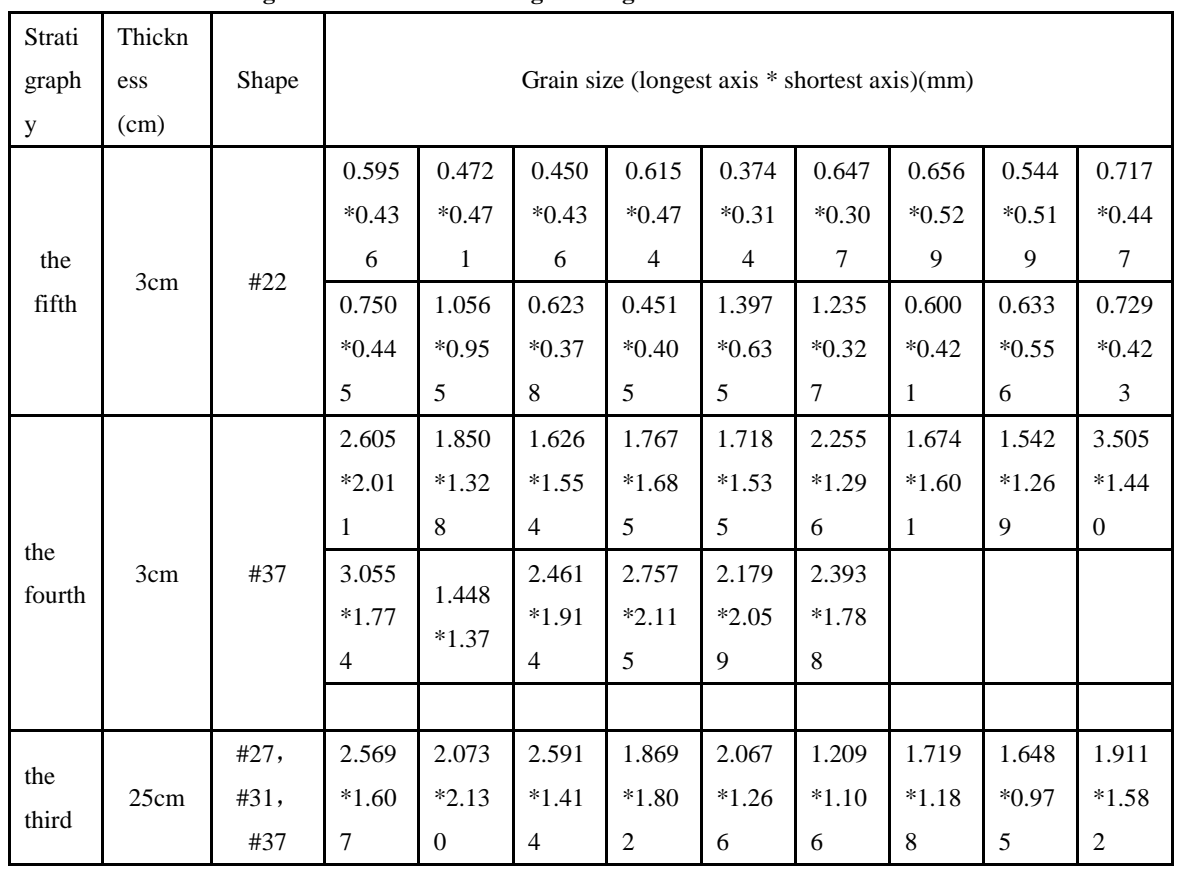




\begin{tabular}{|c|c|c|c|c|c|c|c|c|c|c|c|}
\hline & & & $\begin{array}{l}1.921 \\
* 1.71 \\
0\end{array}$ & $\begin{array}{l}1.518 \\
* 1.06 \\
7\end{array}$ & $\begin{array}{l}1.291 \\
* 1.14 \\
7\end{array}$ & $\begin{array}{l}1.690 \\
* 1.55 \\
1\end{array}$ & $\begin{array}{l}1.756 \\
* 1.39 \\
8\end{array}$ & $\begin{array}{l}1.812 \\
* 1.26 \\
3\end{array}$ & $\begin{array}{l}1.733 \\
* 1.67 \\
2\end{array}$ & $\begin{array}{l}1.880 \\
* 1.51 \\
8\end{array}$ & $\begin{array}{l}2.411 \\
* 1.22 \\
0\end{array}$ \\
\hline & & & $\begin{array}{l}2.118 \\
* 1.72 \\
7\end{array}$ & $\begin{array}{l}1.614 \\
* 1.45 \\
7\end{array}$ & $\begin{array}{l}1.795 \\
* 1.70 \\
5\end{array}$ & $\begin{array}{l}2.215 \\
* 2.31 \\
1\end{array}$ & $\begin{array}{l}1.864 \\
* 1.69 \\
2\end{array}$ & $\begin{array}{l}1.967 \\
* 1.65 \\
1\end{array}$ & $\begin{array}{l}2.008 \\
* 1.39 \\
5\end{array}$ & $\begin{array}{l}1.362 \\
* 1.14 \\
1\end{array}$ & $\begin{array}{l}1.484 \\
* 1.29 \\
1\end{array}$ \\
\hline \multirow{2}{*}{$\begin{array}{l}\text { the } \\
\text { secon } \\
\text { d }\end{array}$} & \multirow{2}{*}{12} & \multirow{2}{*}{$\begin{array}{r}\# 33, \\
\# 34\end{array}$} & $\begin{array}{l}4.251 \\
* 2.26 \\
6\end{array}$ & $\begin{array}{l}3.012 \\
* 2.65\end{array}$ & $\begin{array}{l}2.805 \\
* 1.99 \\
5\end{array}$ & $\begin{array}{l}1.799 \\
* 1.41 \\
5\end{array}$ & $\begin{array}{l}1.402 \\
* 1.19 \\
5\end{array}$ & $\begin{array}{l}3.040 \\
* 2.07 \\
3\end{array}$ & $\begin{array}{l}2.850 \\
* 2.09 \\
5\end{array}$ & & \\
\hline & & & $\begin{array}{l}3.900 \\
* 2.53 \\
2\end{array}$ & $\begin{array}{l}2.420 \\
* 2.33 \\
3\end{array}$ & $\begin{array}{l}2.515 \\
* 2.20 \\
6\end{array}$ & $\begin{array}{l}2.044 \\
* 2.03 \\
2\end{array}$ & $\begin{array}{l}2.506 \\
* 2.36 \\
3\end{array}$ & $\begin{array}{l}2.894 \\
* 2.16 \\
1\end{array}$ & $\begin{array}{l}2.413 \\
* 1.95 \\
0\end{array}$ & $\begin{array}{l}2.494 \\
* 1.81 \\
6\end{array}$ & $\begin{array}{l}4.929 \\
* 3.25 \\
7\end{array}$ \\
\hline \multirow[t]{2}{*}{$\begin{array}{l}\text { the } \\
\text { first }\end{array}$} & \multirow[t]{2}{*}{4} & \multirow[t]{2}{*}{$\begin{array}{r}\# 40, \\
\# 34, \\
\# 38\end{array}$} & $\begin{array}{l}4.933 \\
* 3.37 \\
8\end{array}$ & $\begin{array}{l}3.207 \\
* 2.77 \\
4\end{array}$ & $\begin{array}{l}3.562 \\
* 1.70 \\
1\end{array}$ & $\begin{array}{l}2.818 \\
* 1.66 \\
8\end{array}$ & $\begin{array}{l}3.581 \\
* 2.51 \\
8\end{array}$ & $\begin{array}{l}6.179 \\
* 3.56 \\
2\end{array}$ & & & \\
\hline & & & & & & & & & & & \\
\hline
\end{tabular}

516

517

518

Table A2: One example of record table for snow density observation.

\begin{tabular}{|c|c|c|c|c|c|c|c|}
\hline $\begin{array}{l}\text { observation } \\
\text { date: }\end{array}$ & 20160111 & observation & $19: 03-9: 40$ & weather: & clear & snow depth: & $48 \mathrm{~cm}$ \\
\hline \multicolumn{3}{|c|}{ Snow Folk table } & & \multicolumn{4}{|c|}{ snov tube table } \\
\hline $\begin{array}{l}\text { observation height } \\
(\mathrm{cm})\end{array}$ & $\begin{array}{l}\text { liquid water } \\
\text { content }(6)\end{array}$ & $\begin{array}{l}\text { snow density } \\
(\mathrm{g} / \mathrm{cm} 3)\end{array}$ & & snow depth $(\mathbf{c m})$ & 46.5 & 47 & 47.5 \\
\hline \multirow{3}{*}{5} & 0 & 0.1923 & & snow pressure $(\mathrm{g} / \mathrm{cm} 2)$ & 9.1 & 9 & 9.5 \\
\hline & 0.118 & 0.1882 & & snow density $(\mathrm{g} / \mathrm{cm} 3)$ & 0.1957 & 0.1915 & 0.2000 \\
\hline & 0 & 0.1882 & & & & & \\
\hline \multirow{3}{*}{10} & 0.461 & 0.164 & & \multicolumn{4}{|c|}{ snow shove1 table } \\
\hline & 0.46 & 0.1631 & & observation layer (cm) & weight of shovel+snow $(\mathrm{g})$ & weight of shovel $(\mathrm{g})$ & snoor density $(\mathrm{g} / \mathrm{cm} 3)$ \\
\hline & 0.461 & 0.1361 & & \multirow{3}{*}{$0-10$} & 865.04 & 572.16 & 0.1953 \\
\hline \multirow{3}{*}{15} & 0.123 & 0.2532 & & & 855.72 & 572.16 & 0.1910 \\
\hline & 0 & 0.2506 & & & 866.69 & 572,16 & 0.1964 \\
\hline & 0 & 0.2417 & & \multirow{3}{*}{$10-20$} & 878.58 & 572.16 & 0.2043 \\
\hline \multirow{3}{*}{20} & 0.24 & 0.2159 & & & 887.04 & 572.11 & 0.2099 \\
\hline & 0.119 & 0.2155 & & & 872.79 & 572.16 & 0.2004 \\
\hline & 0.119 & 0.2146 & & \multirow{3}{*}{$20-30$} & 905.34 & 572,16 & 0.2221 \\
\hline \multirow{3}{*}{25} & 0.117 & 0.1977 & & & 903.41 & 572.16 & 0.2208 \\
\hline & 0 & 0.1994 & & & 907.88 & 572.11 & 0.2238 \\
\hline & 0 & 0.1984 & & \multirow{3}{*}{$30-40$} & 832.75 & 572.16 & 0.1737 \\
\hline \multirow{3}{*}{30} & 0 & 0.1919 & & & 838.14 & 572.16 & 0.1773 \\
\hline & 0 & 0.1966 & & & 837.27 & 572.16 & 0.1767 \\
\hline & 0 & 0.1928 & & \multirow{3}{*}{$40-50$} & & & \\
\hline \multirow{3}{*}{35} & 0 & 0.1534 & & & & & \\
\hline & 0 & 0.1517 & & & & & \\
\hline & 0 & 0.1472 & & \multirow{3}{*}{$50-60$} & & & \\
\hline \multirow{3}{*}{40} & 0.325 & 0.1097 & & & & & \\
\hline & 0 & 0.1054 & & & & & \\
\hline & 0.107 & 0.1088 & & & & & \\
\hline \multirow{3}{*}{45} & 0 & 0.0922 & & & & & \\
\hline & 0 & 0.0991 & & & & & \\
\hline & 0 & 0.0928 & & & & & \\
\hline \multicolumn{8}{|l|}{50} \\
\hline & & & & & & & \\
\hline \multirow{2}{*}{55} & & & & & & & \\
\hline & & & & & & & \\
\hline
\end{tabular}




\section{References:}

Babaeian, E., Sadeghi, M., Jones, S.B., Montzka, C., Vereecken, H., and Tuller, M.: Ground, Proximal, and Satellite Remote Sensing of Soil Moisture. Reviews of Geophysics, 57(2), 530-616, doi: 10.1029/2018RG000618, 2019.

Barnett, T.P., Adam, J.C., and Lettenmaier, D.P.: Potential impacts of a warming climate on water availability in snow-dominated regions. Nature, 438, 303-309, doi: 10.1038/nature04141, 2005. Brucker, L., Hiemstra, C., Marshall, H.-P., Elder, K., De Roo, R., Mousavi, M., Bliven, F., Peterson, W., Deems, J., Gadomski, P., Gelvin, A., Spaete, L., Barnhart, T., Brandt, T., Burkhart, J., Crawford, C., Datta, T., Erikstrod, H., Glenn, N., Hale, K., Holben, B., Houser, P., Jennings, K., Kelly, R., Kraft, J., Langlois, A., McGrath, D., Merriman, C., Molotch, N., Nolin, A., Polashenski, C., Raleigh, M., Rittger, K., Rodriguez, C., Roy, A., Skiles, M., Small, E., Tedesco, M., Tennant, C., Thompson, A., Tian, L., Uhlmann, Z., Webb, R., Wingo, M., and Ieee: A FIRST OVERVIEW OF SNOWEX GROUND-BASED REMOTE SENSING ACTIVITIES DURING THE WINTER 2016-2017. 2017

Ieee International Geoscience and Remote Sensing Symposium (pp. 1391-1394), 2017 Che, T., Dai, L.Y., Zheng, X.M., Li, X.F., and Zhao, K.: Estimation of snow depth from passive microwave brightness temperature data in forest regions of northeast China. Remote Sensing of Environment, 183, 334-349, doi: 10.1016/j.rse.2016.06.005, 2016.

Che, T., Li, X., Jin, R., Armstrong, and R., Zhang ,T.J. : Snow depth derived from passive microwave remote-sensing data in China. Annals of Glaciology, 49, 145. doi: 10.3189/172756408787814690, 2008.

Chen, T., Pan, J.M., Chang, S.L., Xiong, C., Shi, J.C., Liu, M.Y., Che, T., Wang, L.F., and Liu, H.R. : Validation of the SNTHERM Model Applied for Snow Depth, Grain Size, and Brightness Temperature Simulation at Meteorological Stations in China. Remote Sensing, 12, 507, doi: Artn 50710.3390/Rs12030507, 2020.

Cline, D., Elder, K., Davis, B., Hardy, J., Liston, G., Imel, D., Yueh, S., Gasiewski, A., Koh, G., Amstrong, R., and Parsons, M.: An overview of the NASA Cold Land Processes Field Experiment (CLPX-2002). Microwave Remote Sensing of the Atmosphere and Environment Iii, 4894, 361-372. doi: Doi 10.1117/12.467766, 2003.

Cohen, J: Snow cover and climate. Weather, 49, 150-156, 1994.

Dai, L. (2020): Microwave radiometry experiment data in Altay (2015/2016). National Tibetan Plateau Data Center [dataset]. doi: 10.11888/Snow.tpdc.270886, 2020.

Dai, L.Y., Che, T., Wang, J., and Zhang, P. :Snow depth and snow water equivalent estimation from AMSR-E data based on a priori snow characteristics in Xinjiang, China. Remote Sensing of Environment, 127, 14-29,. doi: 10.1016/j.rse.2011.08.029, 2012. Derksen, C., Toose, P., Lemmetyinen, J., Pulliainen, J., Langlois, A., Rutter, N., and Fuller, M.C.: Evaluation of passive microwave brightness temperature simulations and snow water equivalent retrievals through a winter season. Remote Sensing of Environment, 117, 236-248, doi: 10.1016/j.rse.2011.09.021, 2012.

Ding, Y.J., Yang, J.P., Wang, S.X., and Chang, Y.P.: A review of the interaction between the cryosphere and atmosphere. Sciences in Cold and Arid Regions, 12 (6): 329-342, doi: 10.3724/SP.J.1226.2020.00329, 2020.

Essery, R.: A factorial snowpack model (FSM 1.0). Geosci. Model Dev. 2015, 8, 3867-3876. 

Covered Area with CMEM in the ECMWF Integrated Forecasting System. Remote Sensing, 12(18), doi: Artn 294610.3390/Rs12182946, 2020.

Immerzeel, W.W., van Beek, L.P.H., and Bierkens, M.F.P.: Climate Change Will Affect the Asian Water Towers. Science, 328(5984), 1382-1385. doi: 10.1126/science.1183188, 2010. FY3B-MWRI in China. Science China-Earth Sciences, 57, 1278-1292, doi: 10.1007/s11430-013-47988,2014

Jordan, R.E.: A One-Dimensional Temperature Model for a Snow Cover: Technical Documentation for SNTHERM.89; U.S. Army Cold Regions Research and Engineering Laboratory: Hanover, NH, USA, 1991. the Swiss avalanche warning Part II: Snow microstructure. Cold Regions Science and Technology, 35, 147-167, Doi 10.1016/S0165-232x(02)00073-3, 2002. Lemmetyinen, J., Kontu, A., Pulliainen, J., Vehvilainen, J., Rautiainen, K., Wiesmann, A., Matzler, C., Werner, C., Rott, H., Nagler, T., Schneebeli, M., Proksch, M., Schuttemeyer, D., Kern, M., and Davidson, M.W.J. : Nordic Snow Radar Experiment. Geoscientific Instrumentation Methods and Data Systems, 5, 403-415, doi: 10.5194/gi-5-403-2016, 2016.

Löwe H. and Picard, G. "Microwave scattering coefficient of snow in MEMLS and DMRT-ML revisited: The relevance of sticky hard spheres and tomography-based estimates of stickiness," Cryosphere, vol. 9, no. 6, pp. 2101-2117, Nov. 2015. of long-term Northern Hemisphere snow water equivalent products. Cryosphere, 14(5), 1579-1594, doi: 10.5194/tc-14-1579-2020, 2020. Permittivity Retrieved From L-Band Radiometry: A Retrieval Sensitivity Analysis. Ieee Journal of Selected Topics in Applied Earth Observations and Remote Sensing, 10(7), 3148-3161, doi:

591 10.1109/Jstars.2017.2669336, 2017.

Pulliainen, J., Luojus, K., Derksen, C., Mudryk, L., Lemmetyinen, J., Salminen, M., Ikonen, J., Takala, M., Cohen, J., Smolander, T., and Norberg, J.: Patterns and trends of Northern Hemisphere snow mass from 1980 to 2018. Nature, 581(7808), 294-298. doi: 10.1038/s41586-020-2258-0, 2020. of the Snow Specific Surface Area. Ieee Transactions on Geoscience and Remote Sensing, 51, 46924704, doi: 10.1109/Tgrs.2012.2235842, 2013. N.: Brightness Temperature Simulations of the Canadian Seasonal Snowpack Driven by Measurements of the Snow Specific Surface Area, IEEE T. Geosci. Remote, 51, 4692-4704, doi:10.1109/TGRS.2012.2235842, 2013 
https://doi.org/10.5194/essd-2022-68

Preprint. Discussion started: 4 March 2022

(C) Author(s) 2022. CC BY 4.0 License.

608 Development, 5, 773-791, doi: 10.5194/gmd-5-773-2012, 2012.

609 Xiao, L., Che, T., and Dai, L.Y.: Evaluation of Remote Sensing and Reanalysis Snow Depth Datasets

610 over the Northern Hemisphere during 1980-2016. Remote Sensing, 12(19), doi: Artn

$611325310.3390 / R s 12193253,2020$.

612 Yang, Z.L., Dickinson, R.E., Robock, A., and Vinnikov, K.Y. : Validation of the snow submodel of the

613 biosphere-atmosphere transfer scheme with Russian snow cover and meteorological observational data.

614 Journal of Climate, 10, 353-373, doi: 10.1175/1520-0442(1997)010<0353:Votsso>2.0.Co;2, 1997. 